\title{
Problem Politik Media Terhadap Korupsi
}

\author{
Mukhijab \\ Jurnalis SKH Pikiran Rakyat Bandung dan Dosen Manajemen Sumber Daya Manusia Media \\ di Prodi Ilmu Komunikasi Universitas Islam Indonesa.
}

\begin{abstract}
This article describes the role of the media to support the eradication of corruption in Indonesia, which is displayed in the form of editorial policy of the media in constructing social reality of corruption cases. Two patterns of reconstruction of social reality as a basis editorial policy, which consists of the reconstruction as rewriting and reconstruction as the actualization of the cultural ideology of journalism by working with certain strategies such as news or reconstructing interpretative facts accompanied by a media crew assessment. Its meaning is, the product should be aligned reconstruction of social reality and is able to transform the values of an anti-corruption into public space. The problem is when the national media or local media that makes governments and institutions that have economic and political power as a strategic partner, the media tend to be politically conservative attitudes or rewriting only in constructing a case of corruption by reason of maintaining objectivity the role of the media. That attitude can be used as an indication that the media in a crisis situation in favor of eradication of corruption
\end{abstract}

Keywords: Media Politic, corruption, reconstruction of reality

\begin{abstract}
Abstrak
Artikel ini menggambarkan peran media untuk mendukung program pemberantasan korupsi di Indonesia, yang ditampilkan dalam bentuk kebijakan editorial dari media dalam mengkonstruksi realitas sosial kasus korupsi. Dua pola rekonstruksi realitas sosial sebagai basis kebijakan politik redaksi, yang tediri dari rekonstruksi sebagai penulisan ulang dan rekonstruksi sebagai aktualisasi ideologi jurnalistik melalui kerja kultural dengan strategi tertentu seperti interpretative news atau merekonstruksi fakta disertai dengan penilaian awak media. Maknanya adalah, produk rekonstruksi realitas sosial harus berpihak dan mampu mentransformasi nilai-nilai anti korupsi ke ruang publik. Masalahnya ketika media nasional atau media lokal yang menjadikan pemerintah dan institusi-institusi yang memiliki kekuatan ekonomi dan politik sebagai mitra strategis, sikap politik media cenderung konservatif atau sekedar menulis ulang dalam mengkonstruksi kasus korupsi dengan alasan memelihara objektivitas peran media. Sikap seperti itu dapat digunakan sebagai indikasi bahwa media dalam situasi krisis dalam mendukung pemberantasan korupsi.
\end{abstract}

Kata Kunci: Politik Media, korupsi, rekonstruksi realitas

\section{Pendahuluan}

Laporan korupsi dalam media menjadi tema seksi. Wakil Ketua Transparensi Internasional Serbia Frank Vogl bercanda, jika seseorang memiliki informasi tentang skandal korupsi yang melibatkan orang penting, jual saja kepada media pasti mau membayarnya. Vogl bermaksud menekankan bahwa program pemberantasan korupsi harus bersinergi dengan media karena institusi ini sangat esensial perannya dalam program pemberantasan korupsi, terutama media yang bebas dan independen dalam mengonstruksi skandal 
korupsi. Vogl mengatakan: "Pers harus terus-menerus mengingatkan masyarakat bahwa tanpa pers benar-benar bebas, (pelaku) korupsi akan selalu merasa lebih aman...Namun orang melawan korupsi menuntut pers yang sepenuhnya independen (www.transparentnost.org. rs/dokumenti/doo6.html). ${ }^{1}$

Perhatian media di Asia, termasuk di Indonesia, terhadap isu-isu korupsi mengalami kemajuan sejalan dengan berbagai survei tentang korupsi sebagai masalah serius di kawasan ini. Kesadaran tentang urgensi pemberantasan korupsi dalam media telah membalik keadaan dari tabu dan sensitif menjadi materi survei dan liputan media yang penting serta membetot perhatian publik. Menurut Jon S.T Quah (1999) mengutip hasil survei Robert Leiken berjudul the Economist, the Financial Times, and the New York Times (1997: 58), isu-isu korupsi menjadi isu seksi ke empat pada kurun waktu 10 tahun (1984 - 1995). Rating isu korupsi tersebut terus meningkat hingga korupsi menjadi isu utama pada tahun-tahun berikutnya. Dalam survei tersebut disebutkan sampel media yang menarik isu korupsi sebagai agenda publik : majalah Economist, koran Financial Times, dan New York Times. Sejumlah televisi dalam perkembangan mutakhir ikut tren mengangkat isu korupsi sebagai pilihan tema yang seksi.

${ }^{1}$ Vogl, Frank, Media dan Corruption, FrankVogel, http://www.transparentnost.org.rs/english/DOCUMENTS/d006 .html, 14 Mei 2010
Virus semangat anti korupsi sebagai liputan media masuk ke ranah media di Indonesia sejak sepuluh tahun silam, bertepatan dengan pendirian Komisi Pemberantasan Korupsi (KPK) pada 2003. Berdasarkan survei Lembaga Penelitian dan Pengembangan Kompas, isu politik dan korupsi menjadi tema utama media-media mainstream. Survei pada 2009, misalnya, pemberitaan utama halaman muka (frontpage) enam surat kabar berskala terbitan nasional, yaitu Koran Tempo, Media Indonesia, Seputar Indonesia, Indopos, Republika, dan Kompas, terdapat 7.524 berita straightnews dan features yang terpantau di halaman muka ke enam surat kabar tersebut, isu pemilu sebanyak 1.473 berita (19,6 persen), sementara isu korupsi sebanyak 1.091 berita (13,4 persen). Beberapa isu besar, seperti terorisme, kriminalitas, dan bencana alam (gempa bumi), besarannya kurang dari 10 persen (Litbang Kompas : 2009). ${ }^{2}$

\section{Problem Perspektif Konstruksi Realitas Sosial}

Politik media dalam mengangkat isu korupsi bisa dikategorikan menjadi dua orientasi dalam memilih paradigma konstruksi realitas sosial. Kelompok media pertama, cenderung konstruksi realitas sosial sebagai penggambaran

\footnotetext{
${ }^{2}$ Litbang Kompas, Mengurai Warna-warni Media Massa, 24 Desember 2009, http://cetak.kompas.com/read/xml/ 2009/12/24/02512945/diunduh 13 Mei 2010
} 
ulang atau rekonstruksi terhadap peristiwa ke dalam tulisan atau cerita maupun visual atau gambar. Prinsip dasar utuh konstruksi tradisional tersebut: penggambaran ulang peristiwa harus netral, tidak boleh berpihak (Siregar, dkk, 1998), dengan dalih menjaga objektivitas. Media yang menganut pemahaman konstruksi demikian, cenderung terjebak pada penyederhanaan problem sosial, misalnya, korupsi sebagai persoalan individual, yang berdampak sektoral.

Kelompok media kedua, menganut strategi mengonstruksi realitas sosial dengan paradigma teori kritis, meskipun perspektif teoretis sering tidak disadari oleh para awak jurnalis. Kerja jurnalistik dipahami bukan sebatas merekonstruksi peristiwa ke dalam bentuk berita, feuture, dan bentuk cerita lainnya. Berpijak pada pemahaman bahwa media sebagai perangkat formasi yang diproduksi dari tindakan mengonstruksi realitas sosial (Severin dan Tankard, 2005), maka produk-produk kerja merekonstruksi realitas sosial bukan sebatas menggambarkan ulang peristiwa secara apa adanya, bagaimana cerita, berita, mencerminkan suatu muatan nilai-nilai ideologi, berpihak pada transformasi sosial, bahkan, mencerminkan konspirasi antara agen media dan kelompok dominan yang mengakses media. Dalam hal ini konstruksi realita sosial dan pelembagaannya dalam media disimbolisasikan sebagai panggung pertarungan agen dan kelompok dominan simbolis
(Harrison, 2006), misalnya, negara, masyarakat sipil atau kelompok lain (Barrat, 1986: 51-52). Timbul pertanyaan, di manakah objektivitas teks atau berita? Menurut Lawrence (2000) -mengutip (Gurevitch dan Levy, 1985),3 berpendapat objektivitas teks atau berita dan karya jurnalistik lainnya sebagai omong kosong, kebenaran ada hanya dari sudut pandang siapa atau kelompok dominan mana yang terbanyak mendefinisikan realitas sosial, atau siapa yang berkongsi untuk merekayasa agenda setting (McCombs dan Reynolds dalam Bryant and Oliver, 2009: 11)

Dalam proses mengonstruksi realitas sosial, agen media menerapkan pendekatan interpretative terhadap informasi (interpretative news). Interpretative news adalah berita yang dikembangkan dengan pendapat atau penilaian wartawan berdasarkan fakta yang ditemukan (Romli, 2009: 12). Dalam perspektif sosiologis dan studi budaya, pendekatan interpretative berita dikenal dengan labeling atau penjulukan terhadap peristiwa dan pelakunya. Charles $\mathrm{R}$. Wright (1985: 145) mencontohkan dua jenis labeling, yaitu peristiwa kejahatan dan pelakunya dilabel penjahat, dan peristiwa heroik dan pelaku dinamakan pahlawan. Pahlawan dimaknai sebagai figur sosial yang memiliki kepribadian sesuai dengan cita-cita budaya

${ }^{3}$ Gurevitch, Michael, and Mark R. Levy. 1985. Preface. Mass Communication Review Yearbook 5, ed. Michael Gurevitch and Mark R. Levy. Beverly Hills: Sage. 
masyarakat, sementara penjahat identik dengan makna figur yang jahat, melawan ketentuan hukum. Contoh model labeling yang ditulis Noam Chomsky (2006; 2008), misalnya, Israel di mata Amerika Serikat sebagai simbol kebaikan manusia (the symbol of human decency) sedangkan Palestina disebut sarang penjahat. Labeling secara ideologis berkaitan identitas kinerja media dalam mengonstruksi realitas sosial bertendensi subjektif atau aktualisasi diri (kelompok kepentingan, korban, jurnalis); mentransformasi ruang publik untuk informasi yang valid, menjaga pluralitas informasi; bertendensi komersial atau menarik minat pasar/konsumen (Allan (ed): 2010, 34-37).

\section{Media Mengemas Keberpihakan Anti Korupsi}

Dalam membaca produk dan orientasi media dari tindakannya mengonstruksi realitas sosial, uraian berikut menyajikan tiga contoh media mengangkat isu skandal pimpinan Komisi Pemberantasan Korupsi (KPK). Kasus ini dikutip dari penelitian penulis pada 2011.4 Tiga sampel media sebagai objek penelitian, yaitu Koran Tempo, Kompas, dan Jurnal Nasional (Jurnas) atau kategori media konvensional (Croteau \& Hoynes: 2002). Sampel berita kasus Antasari periode antara Mei 2009 sampai

\footnotetext{
${ }^{4}$ Penelitian dimaksud untuk persiapan penulisan tesis dengan tema KPK Dalam Bingkai Media pada program magister sosiologi Fakultas IImu Sosial dan Politik Universitas Gadjah Mada.
}

Februari 2010 dan kasus Bibit-Chandra periode Juli sampai Desember 2009. Adapun sampel teks yang dianalisis dipilih secara acak sebanyak 25 teks berita kasus Antasari dan 25 teks kasus Bibit-Chandra. Substansi cerita kedua kasus tersebut, Ketua Komisi Pemberatasan Korupsi (KPK) Antasari Azhar -selanjutnya ditulis kasus Antasari menjadi tersangka pembunuhan terhadap Nasrudin Zulkarnaen (Direktur Putra Rajawali Banjaran, 2009 dan dipidana penjara 18 tahun (http://www. antaranews.com, 4/5/2009), 5 sementara Bibit-Candra singkatan Bibit Samad Rianto dan Chandra M. Hamzah (wakil ketua KPK) -, menjadi tersangka penyalahgunaan kekuasaan (abuse of power) dan suap (http://www.antaranews.com/berita/ 154640) ${ }^{6}$. Proses perkara Bibit-Chandra dihentikan pada tahapan penuntutan, dan Kejaksaan Agung mendeponirnya dengan mengeluarkan Surat Keterangan Penghentian Penuntutan/SKPP (http:// www.antaranews.com/ berita/163051). ${ }^{7}$

Dalam tulisan tesis orisinil dan lengkap, pembongkaran praktik wacana kasus tersebut menggunakan metode analisis wacana kritis Norman Fairclough,

\footnotetext{
${ }^{5}$ Antasari Azhar Dikenai Pasal 340 KUHP, http://www.antaranews.com/berita/139913/antasari-azhardikenai-pasal-340-kuhp, Senin, 4 Mei 2009, diunduh 2010.

${ }^{6}$ Polri Tetapkan Dua Pimpinan KPK sebagai Tersangka Rabu, 16 September 2009, http://www.antaranews.com/berita/154640/polri-tetapkandua-pimpinan-kpk-sebagai-tersangka. diunduh 2010.

${ }^{7}$ Kejagung Pilih Mengeluarkan SKPP Bibit-Chandra Senin, 23 November 2009,

http://www.antaranews.com/berita/163051/kejagung-pilihmengeluarkan-skpp-bibit-chandra, diunduh 2010.
} 
yang secara prinsip memahami konstruksi berita dan membongkar ideologi di balik teks dengan menganalisis teks dan konteks sosial (Titscher, 2009: 238) melalui tiga level analisis, yaitu deskripsi teks (description text) atau menganalisis isi teks media tanpa mengaitkan dengan konteks sosial; interpretasi (procecing analysis) atau menafsirkan produksi dan konsumsi teks dengan mengalisis aspek sejarah media, visi dan perkembangan readership atau oplah media. Berita yang menjadi objek dianalisis dihubungkan dengan proses produksi dan kebijakan politik produksi teks; eksplanasi (social analysis) atau menjelaskan konteks teks dengan praktik sosiokultural. Tahapan ini menganalisis kebijakan media terhadap produksi teks dan sikap politik terhadap kasus Antasari dan kasus Bibit-Chandra (Eriyanto, 2009: 327). Dalam contoh pembacaan konstruksi berikut, penulis menyederhanakan di mana tiga level konstruksi sosial diitegrasikan menjadi kalimat singkat.

\section{Praktik Konstruksi}

\section{1). Koran Tempo}

Koran Tempo mengonstruksi Antasari sebagai sosok penjahat, menjadi aktor intelektual pembunuhan terhadap Nasrudin, sementara Bibit-Chandra dicitrakan positif, tuduhan skandal suap dan menyalahgunakan kekuasan sebagai pimpinan KPK merupakan tindakan rekayasa kepolisian. Sikap politik redaksi memihak atau empati kepada BibitChandra sebaliknya memalingkan Antasari dengan alasan tidak ada ruang untuk bersimpati kepada tokoh publik yang berpetualang seksual.

Menurut Anett Keller

(2009)

Koran Tempo seperti induk semangnya, Majalah Tempo, menganggap dirinya sendiri sebagai "bagian dari ujung tombak modernisasi masyarakat Indonesia”, sebagai clearing house information, media profesional dan demokratis. Visi koran tersebut diuji ketika kasus Antasari dan kasus Bibit-Chandra mencuat. Dalam kasus ini, Koran Tempo menampilkan Antasari sebagai aktor intelektual pembunuhan atau sosok penjahat, sebaliknya Bibit-Chandra bagaikan 'malaikat', 'pahlawan', yang tidak ada celah kesalahannya. Staf redaksi Koran Tempo Dwi Wiyana berpendapat, pembedaan konstruksi dua peristiwa dalam kasus Antasari dan Bibit-Chandra sebagai strategi dan merealisasikan ideologi koran ini dalam mencapai clearing house of information atau rumah penjernih informasi dan meningkatkan pemasaran. ${ }^{8}$ "Kita tidak berpihak pada orang, melainkan kepada kepentingan umum. Ketika sebuah kasus, topik

\footnotetext{
${ }^{8}$ Dwi Wiyana, redaktur desk nasional bidang politik Koran Tempo yang ditunjuk pimpinan redaksi untuk diwawancarai di Redaksi Koran Tempo Jakarta, 24 Januari 2011, dan wawancara via email tanggal 25 Maret 2011. Terkait pencapaian pasar, Dwi Wiyana membantah, dengan alasan mengonstruksi peristiwa hanya membaca dan menafsirkan fakta, tidak secara langsung memikirkan dampak konstruksi terhadap pasar. Pembahasan lebih dalam tentang koran ini lihat Keller, Anett, 2009, Tantangan dari Dalam Otonomi Redaksi di 4 Media Cetak Nasional, Kompas, Koran Tempo, Media Indonesia, Republika, Friedrich Ebert Stiftung, Jakarta
} 
menyangkut hajat hidup orang banyak, kita tulis. Ketika ada even besar, tidak ada urusan publik, misalnya AA Gymnastiar, Zaenuddin MZ (menikah atau cerai), apa kepentingan publiknya?9 (Dwi Wiyana, Staf Redaksi Koran Tempo, Wawancara 24 Januari 2011)

Alasan lebih dalam lagi, "Koran Tempo tak semata membela BibitChandra. Kita membela KPK sebagai institusi. Siapapun orangnya, yang mengalami seperti Bibit-Chandra, kita membelanya. Apalagi dalam kasus ini muncul rekayasa. KPK dipimpin lima orang, kalau tiga pimpinan diambil (diproses hukum dan dipecat,pen), kan menjadi pincang. Kita menyayangkan hal itu.” (Dwi Wiyana, Staf Redaksi Koran Tempo, wawancara 24 Januari 2011).

Dari aspek produksi dan konsumsi media, model konstruksi realitas sosial kedua kasus tersebut meningkatkan readership atau keterbacaan Koran Tempo secara signifikan. Contoh tingkat keterbacaan koran padatahun 2008 sebanyak 233 ribu menjadi 331 ribu pada kuartal ke ketiga tahun 2009. ${ }^{10}$ Pasca kasus Antasari dan kasus Bibit-Chandra, keterbacaan koran ini merosot tajam seperti terlihat dalam tabel di bawah ini.

\footnotetext{
${ }^{9}$ Dwi Wiyana, redaktur desk nasional bidang politik Koran Tempo yang ditunjuk pimpinan redaksi untuk diwawancarai di Redaksi Koran Tempo Jakarta, 24 Januari 2011. Kutipan penjelasan berikutnya tidak ditulis sumbernya untuk menghindari pengulangan-pengulangan, kecuali kutipan diperoleh selain dari wawancara akan disebut sumbernya

${ }^{10}$ Laporan Tahunan PT Tempo Inti Media Tbk 2009, h.44,
} Penerbit Kelompok Tempo Media,www.tempointeraktif.com

\section{Kompas}

Kompas memposisikan Antasari terlibat kasus pembunuhan sebagai domain privat, sebaliknya kasus BibitChandra sebagai peristiwa bertendensi politik, maka menjadi domain publik karena negara bertendensi melemahkan KPK.

Menurut Redaktur Pelaksana Kompas Budiman Tanuredjo, Antasari sebatas mengklaim, tanpa membuktikan bahwa kasus yang mendera dia sebagai rekayasa hukum. Berbeda halnya dalam kasus Bibit-Chandra, indikator rekayasa kasus dan upaya melemahkan upaya pemberantasan korupsi oleh KPK sangat jelas dan memiliki bukti kuat, maka Kompas mendekonstruksi ${ }^{11}$ setiap temuan Polri. Jika media menerima tindakan kepolisian menahan Bibit-Chandra sebagai kebenaran, itu sama halnya media ikut menciderai rasa keadilan.

Ketika Antasari diduga terlibat pembunuhan, Kompas memahami bahwa kasus ini menarik perhatian publik jika dilihat dari posisi Antasari sebagai pimpinan KPK atau figur publik. "Sejak meninggalnya Nasrudin, polisi mulai menangkap sejumlah orang. Rumor mulai muncul bahwa Antasari terlibat dan akhirnya polisi mengumumkan dia

\footnotetext{
${ }^{11}$ Dekonstruksi merupakan metode yang dikembangkan Faucault sebagai cara membaca identitas waana, untuk mengungkapkan asal usul cara berpikir dan menginterpretasikan pemikiran yang berkembang, lihat PIP Jones, 20099, Pengantar Teori-teori Sosial Dari Teori Fungsionalisme hingga Pos-Modernisme, Yayasan Obor Indonesia, h.204.
} 
sebagai aktor intelektual..."12 Kompas semula menunggu dan melihat perkembangan dalam menyikapi kasus ini. Redaksi Kompas merasa on the track visi pemberitaannya ketika KPK mengumumkan bahwa Antasari tersangkut tindak pidana dalam kapasitas pribadi.

"Political standing media melihat bagaimana statemen lembaganya. KPK mengatakan itu semata-mata urusan Antasari pribadi, bukan upaya penjeratan Antasari sebagai ketua KPK. Kemudian kewenangan (dan jabatan) Antasari dilepas, digantikan empat wakilnya. Itu menunjukkan empat pimpinan KPK mau mengonstruksi apa yang dilakukan Antasari di luar pekerjaan sebagai pimpinan KPK. Itu kebenaran jurnalistik yang terungkap.” (Budiman Tanuredjo, Redaktur Pelaksana Kompas, wawancara 14 Januari 2011).

Adapun basis politik redaksi Kompas terhadap kasus Bibit-Chandra, menurut Budiman, manajemen redaksi melakukan lompatan kebijakan dari jurnalisme kepiting atau konservatif dalam istilah Jacob Oetama ke jurnalislisme kritis. "Advokasi Kompas begitu total terhadap Bibit-Chandra. Kami sempat berpikir andaikata Bibit-Chandra benar-benar menerima uang, bagaimana kredibilitas media? Kompas melakukan

\footnotetext{
${ }^{12}$ Kutipan-kutipan dalam penjelasan tersebut berdasarkan wawancara penulis dengan Budiman Tanuredjo di Redaksi Kompas, Jakarta, Jumat, 14 Januari 2011. Budiman merupakan redaktur senior yang ditunjuk untuk diwawancarai oleh penulis. Dalam penulisan berikutnya, pernyatan atau keterangan Budiman dikutip langsung, penulis tidak menyebutkan ulang nama Budiman untuk alasan efisiensi atau tidak terjadi pengulangan, kecuali kutipan baru dari sumber lain
}

dekonstruksi kasus Bibit-Chandra, itu pengalaman pertama kali." (Budiman Tanuredjo, Redaktur Pelaksana Kompas, wawancara 14 Januari 2011).

Sikap advokatif Kompas dalam kasus Bibit-Chandra dianggap keniscayaan dan tidak bisa digeneralisasi dalam kasus lain. Manajemen redaksi Kompas menyadari sikap demikian sangat berisiko.

"Bagaimana masalah media responsibility? Saya katakan dalam kasus (penyalahgunaan wewenang dan suap sebagaimana disangka polisi, pen), mereka (Bibit-Chandra) tidak salah (tak terbukti, pen). Dalam kasus lain, Bibit-Chandra bisa saja salah. Kompas menganggap there are not be angel, tidak ada orang yang menjadi malaikat (bersih sama sekali, tanpa kesalahan, pen).” (Budiman Tanuredjo, Redaktur Kompas, wawancara 14 Januari 2011).

Menyangkut dimensi politik produksi dan konsumsi media, menurut Budiman, Kompas sekadar memberi pemaknaan fakta-fakta yang bergerak dan berkembang dalam mengonstruksi kasus Antasari dan kasus Bibit-Chandra. Tidak ada pertimbangan bisnis, oplah Kompas stagnan saja selama kedua kasus tersebut menjadi perhatian publik dan dipublikasikan koran ini. ${ }^{13}$ Alasan lain, Budiman tidak sependapat dengan Jakob Oetama bahwa berita identik sebagai

\footnotetext{
${ }^{13}$ Lihat Swantoro (redaktur), 1990, Membuka Cakrawala 25 Tahun Indonesia dan Dunia dalam Tajuk Kompas, Penerbit PT Gramedia, JakartaPenerbit PT Gramedia, Jakarta, untuk memahami kebijakan politik redaksi koran ini.
} 
komoditi, yakni berita semakin menarik perhatian publik berarti semakin banyak pembaca, yang berarti juga semakin banyak oplah koran. Menurut dia, oplah koran tumbuh seiring dengan tercapainya kredibilitas dan kepercayaan masyarakat terhadap koran, bukan oleh peristiwa harian. Kompas menanggapi kredibilitas dan kepercayaan tersebut sedikit demi sedikit dari tahun ke tahun hingga usia 45 tahun. "Ketika integritas tercapai, industri bisnis media akan terdongkrak tirasnya melalui advertising. Tidak ada insideninsiden (peristiwa) harian menaikkan oplah koran (lihat Tabel 10)." (Budiman Tanuredjo, Redaktur Pelaksana Kompas, wawancara 14 Januari 2011).

\section{Jurnas}

Koran ini cenderung mencitrakan kedua kasus tersebut secara negatif. Antasari terlibat pembunuhan Nasrudin dengan meminjam tangan orang lain dan selama aktif memimpin KPK menghambat proses hukum terhadap lawan-lawan politik Presiden Susilo Bambang Yudhoyono, sementara Bibit-Chandra sebenarnya menyalahi wewenang dan menerima suap. Karena masyarakat sipil protes dan menekan penegak hukum sehingga kedua wakil pimpinan KPK tersebut dibebaskan dari tanggungjawab hukum.

Dalam skandal pembunuhan yang melibatkan Antasari, Jurnas memilih konstruksi awal sebagai kasus konspirasi dengan dasar pemikiran sebagai berikut:
"Kita ingin mencari kebenaran faktual. Antasari mengatakan kasus yang menimpa dirinya bagian dari konspirasi. Kita sampaikan masalah ini dengan mengutip pernyataan pengacara maupun pengadilan. Kita tidak ingin masuk ranah politik, kasus ini kaitannya dengan hukum. Pengadilan memutuskan bahwa Antasari bersalah, itu fakta hukum yang harus disampaikan media. Konspirasi tidak pernah ada bukti." 14 (Wahyudi M. Pratopo, Pemimpin Redaksi Jurnas, wawancara 15 Januari 2011).

Sementara dalam kasus BibitChandra, Menurut Pemimpin Redaksi Jurnas Wahyudi M. Pratopo, kedua komisioner tersebut terlibat pelanggaran hukum, maka anggota KPK memiliki posisi hukum yang sederajat dengan anggota masyarakat lain, tidak boleh ada perlakukan khusus di depan hukum terhadap anggota KPK.

"Bibit-Chandra ikuti saja proses hukum itu. Saya kira ada (pemikiran internal Jurnas bahwa skenario polisi benar dan pernyataan Presiden Susilo Bambang Yudhoyono tepat sasaran). Kemudian pimpinan KPK tidak kebal hukum. Mereka bisa tersangkut pelanggaran hukum. Kami mengemas aspek profesionalitas dan adil bagi anggota KPK, sebenarnya sesuatu yang normatif saja." (Wahyudi M.

\footnotetext{
14 Pendapat Wahyudi M. Pratopo dikutip dari wawancara penulis di Redaksi Koran Jurnas Jalan Johar 8 Menteng, Jakarta Pusat, Sabtu, 15 Januari 2011. Semua kutipan pendapat Wahyudi dalam analisis ini berdasarkan wawancara dimaskud. Agar mengurangi pengulangan catatan kaki, kutipan tentang Wahyudi tidak dikode catatan kaki lagi, kecuali diambil dari sumber lain di luar wawancara
} 
Pratopo, Pemimpin Redaksi Jurnas, wawancara 15 Januari 2011).

Adapun Koran Jurnas mengubah haluan politik redaksi bahwa kasus BibitChandra direkayasa oleh pihak-pihak berkepentingan setelah memperoleh fakta-fakta pendukung, misalnya Mahkamah Konstitusi memutar rekaman percakapan telepon makelar kasus Anggodo Widjojo dengan para relasi kekuasaan, seperti pejabat di Kepolisian RI dan Kejaksaan Agung. ${ }^{15}$

Orientasi ideologi media ini sangat berbeda dengan Koran Tempo dan Kompas. Konstruksi peristiwa penting yang berpengaruh pada pemerintah (baca $=$ presiden) dan publik, konstruksi dan frame-nya cenderung berpihak pada kekuasaan. Alasan utamanya Presiden Yudhoyono sebagai penggagas penerbitan koran ini. Memadukan kepentingan politik dan bisnis, sepertinya perjuangan yang menantang bagi koran ini. Jurnas seperti merevitalisasi jurnalisme tradisional, korannya menjadi ajang aktualisasi para agen konstruksi dan relasi politik atau panggung penguasa serta mengklaim kebenaran sebelum menemukan faktar Sehingga

\footnotetext{
${ }^{15}$ Anggodo Widjojo, tersangka percobaan penyuapan terhadap pimpinan KPK. Dia adik dari Anggoro Widjaja, Direktur Utama PT Masaro Radiokom. Anggoro Widjaja berstatus tersangka korupsi pengadaan peralatan komunikasi di Departemen Kehutanan, masuk daftar pencarian orang (DPO). Anggodo Widjaja menjalin koneksi dengan pejabat Polri dan Kejaksaan untuk merekaya bahwa Bibit-Chandra menerima suap dari Anggoro Widjaja. Hubungan Anggodo dan relasi-relasi kekuasaan disadap petugas KPK dan produk sadapan diputar di Mahkamah Konstitusi pada 3 November 2009, lihatDua Pimpinan KPK Ditahan, Rekaman Percakapan Anggodo-Yuliana Gunawan Wanita yang diduga Yuliana Gunawan menyebut nama Presiden SBY, 4 November 2009, www.vivanews.com
}

operasionalisasi visi Jurnas dalam konteks membela publik menjadi semu.

"Seorang penggagas Jurnas adalah Susilo Bambang Yudhoyono. Pemikirannya tentang jurnalisme positif, kebijakan redaksi yang mencerahkan, optimistik, merupakan pemikiran pendiri. Redaksi melaksanakan visi dan misi pendiri. Kapasitas penggagas sebagai pribadi. Masalahnya, orang susah untuk memisahkan (kapasitas) pribadi dan (jabatan) presiden," kata Wahyudi (Wahyudi M. Pratopo, Pemimpin Redaksi Jurnas, wawancara 15 Januari 2011).

\section{Korupsi Tanpa Keberpihakan Media Problem Inkonsistensi}

Tiga media sampel di atas menampilkan dua warna kebijakan politik redaksi dalam mengonstruksi peristiwa Antasari dan Bibit-Chandra. Koran Tempo dan Kompas memiliki konsistensi dalam mempertahankan lembaga anti korupsi dengan menempatkan kasus Bibit-Chandra sebagai skandal politisasi oleh kekuasaan, yang bertujuan menghancurkan lembaga anti rasuah (KPK), maka sikap demikian bisa dibaca sebagai komitmen mendorong pemberantasan korupsi, mengoyak perasaan para koruptor menjadi tidak aman, sementara Jurnas cenderung ambigu dengan mengonstruksi bahwa kasus Antasari sebagai kejahatan yang dipolitisasi oleh lawan-lawannya bertujuan menghambat proses hukum di KPK, sebaliknya BibitChandra benar-benar melakukan 
kejahatan menyalahgunakan kekuasaan dan menerima suap, meskipun ketika semua media mengonstruksi berlawanan dengan koran ini, akhirnya Jurnas mengubah kebijakan redaksinya. Orientasi tiga media dalam sampel penelitian penulis dengan dua model konstruksi realitas sosial memantik pertanyaan, apakah komitmen media terhadap program anti korupsi bisa konsisten dalam jangka panjang?

Aspek penting dalam politik media adalah dinamika kekuasaan yang sangat berpengaruh terhadap kebijakan media. Bahkan kaum Marxian meletakkan hipotesis bahwa orientasi politik media dan relasi kekuasaan dengan institusi kekuasaan mengalami perubahan bersamaan dengan terjadinya perubahan rezim kekuasaan. Dengan kalimat lain, relasi dan kebijakan politik media sangat ditentukan oleh struktur kekuasaan dan ekonomi (McQuail, 2011). Pada masa tradisi kekuasaan dari rezim Orde Lama ke Orde Baru pada dekade 1970-an, Alatas (1986) mencatat semangat anti korupsi merasuki pemerintah Presiden Soeharto dan media. Pemerintah membongkar skandal mega-korupsi di Pertamina yang dilakukan oleh pejabat-pejabat masa pemerintahan Presiden Soekarno, sementara media dengan antusias mengonstruksi isu tersebut sebagai tema pilihan. Dalam konteks tersebut pemerintah membuka kran kebebasan berekspresi termasuk kebebasan media dalam menentukan pilihan konten media.
Usai skandal Pertamina dibongkar, pertumbuhan perekonomian nasional terus membaik, pemerintah dan media melupakan pentingnya menjaga komitmen anti korupsi secara berkelanjutkan. Rezim Orde Baru tumbuh kuat dan menjelma menjadi otoriter, sebaliknya posisi kekuatan media makin melemah. Dalam tekanan kuat dari kekuasaan, media mengalami disorientasi dan gagal menjaga momentum menjadikan media sebagai ruang publik (public sphare), yang terjadi justru media mengalami metamorfosis menjadi arena propaganda pemerintah Orde Baru. Fungsi media tidak jalan sebagai watchdog dalam penyelenggaraan kekuasaan dan program anti korupsi mati suri (Faruk, Soemanto, Purwanto, 2000:6), karena media menjadi bagian yang mengalami overdominasi dari pemerintah, menjadi subaltern, yang ikut masuk dalam jebakan hegemoni kekuasaan (penjelasan hegemoni lihat Laclau dan Mouffe, 2008).

Harga mahal dari inkonsistensi menjaga keberpihakan pemberantasan korupsi, sebagaimana Klitgaard (1998) melukiskan bahwa orang Indonesia sebagian besar tampaknya pasrah pada korupsi dan nepotisme selama ekonomi terus tumbuh delapan persen setahun pada masa kekuasaan Presiden Soeharto. Sikap demikian menjadi bumerang ketika korupsi tumbuh menjadi penyakit kanker yang menggerogoti sendi-sendi perekonomian nasional hingga akhirnya krisis ekonomi dan politik membuncah 
pada 1997. Faktor kekuasaan dan kroni Soeharto menjadi sumbu utama penyulut krisis karena Soeharto dan keluarganya menghimpun kekayaan mencapai 30 miliar dolar AS.

\section{Pluralitas Media Potensi Atau Ancaman?}

Era desentralisasi atau otonomi daerah yang berlaku berdasarkan UU Nomor 22 Tahun 1999 tentang Otonomi Daerah, menumbuhkan era baru industri media. Jika selama era pemerintahan sentralistik Orde Baru (1966 - 1998), struktur media hanya mengenal kategori media nasional dan regional, era otonomi daerah menumbuhkan media lokal atau media berbasis pasar pada kabupaten/ kotamadya tertentu. Otonomi daerah menjadi momentum pergeseren pendulum ekonomi yang selama ini terpusat di Ibu Kota dan sekitarnya, pusaran modal bergerak dari pusat ke daerah, dan perubahan ini yang menjadi magnet para investor untuk mengembangkan bisnis media di daerah. Mereka menanamkan modal untuk menerbitkan media lokal, baik media cetak, radio maupun televisi (Luwarso, 2002; Nugroho, Siregar, Laksmi, 2012; Lim, 2011). Suatu langkah bisnis yang tidak terjadi pada masa sebelumnya karena rezim Orde Baru alergi terhadap istilah lokal, yang berkonotasi independensi politik daerah dan anti pemerintah pusat (Siregar, 2002).
Terdapat masalah mendasar dalam bisnis media era desentralisasi: yaitu pembaca media cetak cenderung semakin menurun, sebaliknya pemirsa televisi makin meningkat; pangsa pasar media cetak di daerah (regional dan kabupaten/kota) relatif kecil. Begitu pula potensi pasar iklan, sebagian besar hanya dinikmati oleh media mainstream, media lokal milik perseorangan tidak mendapatkan iklan yang memadai (Manan, 2010). Maknanya pasar media cetak yang terbatas, baik dari sirkulasi/ tiras maupun konsumsi iklan, memicu persaingan bisnis tidak sehat antarmedia lokal maupun media lokal dan media nasional, misalnya perang harga eceran media cetak dan tarif iklan. Dalam kasus perang harga, perusahaan media konglomerasi dituding sebagai pencetus strategi bisnis yang destruktif atau persaingan tidak sehat tersebut sebagai taktik meningkatkan persebaran produk media dan rating pembaca. Elevasi persebaran produk dan keterbacaan media cetak menjadi pertaruhan untuk menarik pemasang iklan. Dengan demikian desentralisasi dengan kebijakan pemekaran daerah yang diikuti perputaran modal di daerah-daerah yang diasumsikan menjadi ladang pasar baru media cetak maupun media lain), menyimpan masalah besar bagi perusahaan media cetak. Contoh, kasus pers lokal (cetak) di Kalimatan, perusahaan media setempat dimiliki oleh perseorangan dari kalangan pejabat dan 
politisi maupun media milik jaringan perusahaan media. Media yang bernaung di perusahaan manapun cenderung memposisikan pemerintah daerah sebagai basis sumber informasi, basis pasar dan basis pengawasan yang dikonstruksi sebagai tugas ideologi media dalam mentransformasi kepentingan publik. Dengan memposisikan pemerintah daerah yang demikian, apakah media mampu menjaga independensi dan mentransformasi ke publik skandal korupsi? (Sulhan, 2006). Kemudian penelitian Tim LSPP terhadap orientasi pemberitaan media di Jabar, Lampung, Kalimantan Barat, Nusa Tenggara Barat, menunjukkan media memerlukan sandaran pemerintah daerah untuk mendapatkan kue iklan, pemasaran media, dan bantuan pembinaan jurnalis. Akibatnya muncul problem independensi dari internal media dalam menghadapi skandal-skandal korupsi dan kasus lain yang mendera pejabat dan elemen pemerintah daerah. Dalam mengonstruksi peristiwa skandal korupsi, media di daerah lebih banyak mengonstruksi skandal korupsi oleh anggota dewan, sementara pelaku korupsi di birokrasi pemerintah sering tidak menjadi pilihan pemberitaan (Ibrahim dan Marpaung, 2005). Kebijakan media dalam mengonstruksi realitas sosial di institusi pemerintah hanya menggambarkan ulang kisah sukses pemerintah. "Konten media mirip parade keberhasilan pemerintahan daerah, karena seluruh berita tentang penyim- pangan dan ketidakberesan telah diredam di meja redaksi. Yang terjadi adalah ketimpangan informasi yang dikendalikan sepenuhnya oleh pihak-pihak yang memegang kuasa” (Sulhan, 2006: 332).

Problem resistensi muncul ketika agen media melawan arus, dengan bersikap kritis terhadap skandal korupsi di birokrasi pemerintah dan kelompok kepentingan terkait. Kasus kekerasan terhadap jurnalis menjadi cerminan resistensi dimaksud (Manan, 2010), ${ }^{16}$ dan terjadi masalah besar bagi media dalam strategi mendefinisikan realitas karena kelompok dominan menuntut media harus mendefinisikan nilai dan perilaku yang sesuai dengan nilai kelompok dan perilaku tersebut meskipun fakta menunjukan kelompok dominan tersebut dalam posisi bersalah, melanggar norma sosial dan hukum. Tugas media untuk merekonstruksi realitas sosial secara profesional dan aktif mendefinisikan realitas sosal secara objektif dalam standar profesionalisme jurnalistik menjadi tergangu (lihat Eriyanto, 2009: 113). Apakah problem tersebut hanya melekat pada media daerah? Sesuai penelitian penulis 2011, satu dari tiga media sampel mengalami "masuk angin” atau tidak jelas posisnya terhadap isu

\footnotetext{
${ }^{16}$ Tragedi sangat memilukan dalam kasus pembunuhan Prabangsa, wartawan Harian Radar Bali, 11 Februari 2009, karena dia memberitakan penyimpangan proyek-proyek di Dinas Pendidikan Bangli, khususnya proyek TK dan SD internasionalpada 3, 8, dan 9 Desember 2008. Kasus yang mirip terjadi pada wartawan Bernas, Fuad Muhammad Syafrudin, dibunuh oleh pria misterius pada 13 Agustus 1996 karena memberikan dugaan korupsi berbagai proyek di Kabupaten Bantul.
} 
pemberantasan korupsi dalam kasus pelemahan terhadap KPK. Pelajaran dari situasi tersebut bahwa pluralitas media (nasional, regional, lokal) tidak menjamin makin meluas dan banyak media yang berpihak pada program anti korupsi.

Pakar anti korupsi Jeremy Pope (2008) berpendapat indikasi korupsi bisa meluas dan mengakar ketika media makin tumpul dalam fungsi kontrolnya terhadap pemerintah dan peradilan serta lembaga kekuasaan lainnya. Dia menekankan pentingnya media yang kuat keberpihakannya terhadap program anti korupsi suatu negara jika suatu negara serius menjauhkan dari korupsi karena kekuatan media dan informasi melebihi pengadilan yang independen. "Informasi adalah kekuasaan, tidak ada informasi jika tak ada tanggung gugat. Media yang bebas sama pentingnya dengan peradilan yang independen. Tingkat kebebasan media adalah tingkat yang dapat dicapai untuk melaksanakan fungsi pengawasan yang efektif atas perilaku pejabat publik. Namun disadari, media punya peranan khusus dan titik-titik lemah untuk mengungkap korupsi...”(Pope, 2008: 18).

Kelemahan media dalam konteks Indonesia berakar dari problem ekonomi media. Berlaku suatu hukum pasar, media bermasalah dari segi basis pasar dan komodifikasi produknya, semakin mendekat dan melakukan instrumenttalisasi terhadap kekuasaan (Haryanto dalam Nugroho, 2011: 15). Fenomena ini bertentangan dengan karakter industri media modern, antara lain, pengelola memiliki kebebasan dalam mengelola pemberitaan, dalam kesesuaiannya dengan kebutuhan khalayaknya; konstruksi realitas sosial (berita dan bentuk tulisan lain) berorientasi pada kebutuhan khalayak (audience oriented) bukan kebutuhan kekuasaan (message oriented); kelangsungan hidup industri media terletak pada kemampuannya menghasilkan profit baik berasal dari para pelanggan media maupun iklan (Rahayu, 2010: 109-110), bukan mengandalkan pemerintah. Dengan terjadinya kontradiksi kondisi objektif media tersebut, maka keberpihakan media dalam mengawal program bersih atau anti korupsi bisa mengalami krisis. Ketika media mandul dalam menjalankan fungsi kontrol terhadap kekuasaan, korupsi merajalela dan pelaku merasa aman, kanker korupsi bisa kambuh lagi seperti pada masa lalu.

\section{Kesimpulan}

Strategi penting untuk mengekspresikan komitmen anti korupsi dalam institusi media bisa ditunjukkan dalam bentuk kebijakan politik media dalam mengonstruksi realitas sosial yang benar dan jelas berpihak pada program anti korupsi. Kemajuan besar ketika media di Indonesia pasca Orde Baru menjadikan isu korupsi sebagai bagian dari tema utama dalam media. Energi positif dari politik media berpihak pada anti korupsi 
memerlukan konsistensi untuk menjaga komitmen yang berkelanjutan. Problem yang mencuat bahwa media nasional tumbuh dan berkembang dengan basis ekonomi dan sosial yang beragam, bahkan, sebagian media mengalami masalah dari aspek pasar maupun politik redaksi. Jalan pintas media mengatasi masalah tersebut dengan merapat ke kutub kekuasaan untuk memperoleh pasokan amunisi iklan dan pelanggan. Kecenderungan demikian dilakukan media mapan sekalipun karena potensi ekonomi pemerintah dan kelompok kekuasaan di daerah sangat besar, yang berarti potensi pendapatan iklan dan bentuk lain (subsidi pembinaan media, misalnya). Ketika independensi dan ideologi media tersandung oleh jerat ekonomi dari kekuasaan dan tumbuhnya kekuasaan yang mengendalikan media, maka kontrol terhadap program anti korupsi oleh media bisa mengalami distorsi, sebaliknya korupsi menjamur dan pelaku korupsi merasa aman. ${ }^{* * *}$

\section{Daftar Pustaka}

Alatas, Syed Hussein Ali, 1986, Corruption and the Destiny Asia, Second Edition, Times Book International Singapore.

Allan, Stuart (Editor), 2010, News and Journalism, The Routledge Companion, New York.

Barrat, David, 1986, Media Sociology Society Now, Taylor \& Francis Routledge, London and New York.

Bryant, Jennings and Oliver, Mary Beth (Ed), 2009,Media Effects Advances in Theory and Research, Third Edition By Routledge 270 Madison Ave, New York, 2009.

Croteau, David dan Hoynes, William, 2002, Media Society, Industries, Images, and Audiences, Third Edition, Pine Forge Press, New Delhi.
Chomsky, Noam, 2006, Politik Kuasa Media (Media Control: The Spectaculer Achievements of Propaganda) editor Aan Mansyur, Pinus Book Publiser.

---------, 2008, Neo Imperalisme Amerika Serikat, Resist Book.

Darma, Yoce Aliah, 2009, Analisis Wacana Kritis, Yrama Widya Bandung.

Eriyanto, 2009, Analisis Wacana, Pengantar Analisis Teks Media, LKiS

Faruk, Soebakdi Soemanto, dan Purwanto, 2000, Perlawanan Atas Diskriminasi Rasial-Etnik. Konteks Sosial-Ideologis Kritik Sastra Tionghoa Peranakan Tahun 1970-an dan Tahun 1980an, Magelang: Yayasan Indonesia Tera. 
Ibrahim, Idi Subandi dan Marpaung, Rusdi (ed) : 2005), Media Sadar Publik, Media Lokal Mewartakan Korupsi dan Pelayanan Publik, Penerbit Open Society Institute dan Lembaga Studi Pers dan Pembangunan Jakarta

Hamad, Ibnu, 2004, Konstruksi Realitas Politik dalam Media Massa, Granit Bandung.

Harrison,Jackie, 2006, News, Routledge, London and New York.

Jones, PIP, 20099, Pengantar Teori-teori Sosial Dari Teori Fungsionalisme hingga Pos-Modernisme, Yayasan Obor Indonesia.

Keller, Anett, 2009, Tantangan dari Dalam Otonomi Redaksi di 4 Media Cetak Nasional, Kompas, Koran Tempo, Media Indonesia, Republika, Friedrich Ebert Stiftung, Jakarta.

Klitgaard,Robert, 1998,Strategies against Corruption, e-book CLAD; Agencia Española de Cooperación Internacional

Laclau, Ernesto; Mouffe, Chantal, 2008, Hegemoni dan Strategi Sosialis Post Marxisme + Gerakan Sosial Baru (Hegemony and Socialist Strategy: Toward Radical Democratic Politics) alih bahasa Eko Prasetyo Darmawan, Penerbit Resist Book, Yogyakarta

Lim, Merlyna, 2011, @crossroads: democratization \& corporatization of media in Indonesia, Penerbit Participatory Media Lab, Arizona State University\& Ford Fondation.

Luwarso et.al, 2002, Data Penerbitan Pers Indonesia 2001, Dewan Pers.

Manan; Abdul, 2010,Ancaman Itu Datang dari Dalam, Laporan tahunan aliansi jurnalis independen 201O, Penerbit AJI Jakarta.
McQuail, Denis, 2011,Teori Komunikasi Media Massa McQuail (McQuail Communication Theory) edisi 6 alih bahasa Putri Iva Izzati, Penerbit Humanika Jakarta dan Sage Publication.

Nugroho, Bekti, 2011,Profesionalisme, Sejarah, dan Masa Depan Pers Daerah, Penerbit Dewan Pers Jakarta, Jurnal Dewan Pers, Edisi No.5 Mei 2011

Nugroho, Siregar, Laksmi: 2012, Mapping the landscape of the media industry in contemporary Indonesia, Penerbit Centre for Innovation Policy and Governance, Jakarta
Pope, Jeremy, 2008, Strategi Memberantas Korups (Edisi Ringkas), Perbit TI dan TI Indonesia.

Quah, Jon S.T., 1999,Comparing Anticorruption Measures in Asian Countries: Lessons to be Learnt, Asian Review of Public Administration, Vol. XI, No. 2 (JulyDecember)

Ritzer, George dan Goodman, 2009, Teori Sosiologi Dari Teori Klasik sampak Postmodernisme, Kreasi Wacana, Yogyakarta.

Romli, Asep Syamsul. 2009.,Jurnalistik Praktis Untuk Pemula. Bandung: Remaja Rosdakarya.

Severin, Wernet J dan Tankard, W. James, Jr, 2005, Teori Komunikasi, Sejarah, Metode dan Terapan di Dalam Media Massa (Communication Theories : Origin, Methods and Uses in the Mass Media) penerjemah Sugeng Hariyanto, Prenada Media, Jakarta

Siregar, Ashadi,dkk,1998, Bagaimana Meliput dan Menulis Berita untuk Media Massa, $L P_{3} Y$ 
Strentz, Herbert, 1998,Reporter dan Sumber Berita Persekongkolan Dalam Mengemas dan Menyesatkan Berita (News Reporters and News Sources Accomplices in shaping and misshaping the news, scond edition, 1998), penerjemah Truly Wangsalegawa, PT Gramedia Jakarta

Swantoro (redaktur), 1990, Membuka Cakrawala 25 Tahun Indonesia dan Dunia dalam Tajuk Kompas, Penerbit PT Gramedia, Jakarta

Titscher, Stefan, dkk., 2009, Metode Analisis Teks dan Wacana (Methods of Text and Discourse Analysis), penerjemah Gazali,dkk, Pustaka Pelajar, Yogyakarta

Wright, Charles R., 1985Sosiologi Komunikasi Massa (Mass Communicatio: A Sociological Perspective Second Edition) penerjema Lilawati Trime, Jalaluddin Rakhmat, Penerbit, Remaja Karya Bandung

\section{Jurnal dan Paper:}

Siregar, Ashari, 2002, Perkembangan Media Cetak Lokal, Makalah disampaikan pada Seminar Nasional Being Local in National Context: Understanding Local Media and Its Struggle, Universitas Kristen Petra, Surabaya 14 Oktober 2002

Sulhan, Muhammad, 2006,Kisah Kelabu di Balik Maraknya Pers Lokal di Kalimantan dalam Jurnal Ilmu Ssial dan Politik, Volume 9, Nomor 3, Maret 2006 (255-270)

Rahayu, 2010, Analisis Dampak Pergeseran Karakteristik Industri Pers pad Strategi Perusahaan dan Pengembangan Sumber Daya Manusia, Jurnal Ikatan Sarjana Komunikasi Indonesia, No.5/Oktober 200o, h.109-11o

Vogel, Frank,Media dan Corruption, , Vice Chairman, Transparency International Wakil Ketua, Transparency International,http://www.transp arentnost.org.rs/english/DOCUM ENTS/doo6.html , 14 Mei 2010. 